\title{
Factors Influencing the Performance of Technology Transfer Offices: the Case of the European Consortium of Innovative Universities
}

\author{
${ }^{1}$ University of South-Eastern Norway \\ PO Box 235, NO-3603, Kongsberg, Norway \\ E-mail.ruta.zmuidzinaite@usn.no \\ ${ }^{2}$ Startup Norway \\ Chr. Krohgs gate 1, NO-0186, Oslo, Norway \\ E-mail.sandra@startupnorway.com \\ ${ }^{3}$ Kaunas University of Technology \\ K. Donelaicio st. 73, LT-44029, Kaunas, Lithuania \\ E-mail.lina.uziene@ktu.lt \\ cross $^{\text {ref }}$ http://dx.doi.org/10.5755/j01.ee.32.3.25785
}

Ruta Zmuidzinaite ${ }^{1}$, Sandra Zalgeviciene ${ }^{2}$, Lina Uziene ${ }^{3}$

Technology transfer offices (TTOs) play an important role in innovation ecosystems. There is a global strive to make these offices more efficient and improve their performance. This study aims to reason the key factors influencing the performance of TTOs at the members of the European Consortium of Innovative Universities (ECIU). To reach this aim, the comparative literature review of the factors influencing the performance of the TTOs was performed first. The survey along with the semi-structured interviews interviewing leaders of the TTOs with the aim to validate the relevance of the factors was conducted afterwards. The discussion on the key factors influencing the performance of TTOs at ECIU members is presented at the end of the study. The study reveals the following as the key factors influencing the performance of TTOs at the ECIU network: i) TTO strategy; ii) relationships with investors; iii) networking; iv) functioning of a special TTO unit dedicated to working with industry; and v) business experience of TTO staff. It also brings an extension to the technology transfer literature by discussing organizational issues of technology transfer in the European context. The study reveals that the key factors influencing the performance of TTOs at ECIU members are quite similar regardless of the age of TTOs or the country of operation.

Keywords: Technology Transfer; Technology Transfer Office; European Consortium of Innovative Universities; Performance; Factors.

\section{Introduction}

It is widely accepted that one of the essential sources of a country's economic growth is knowledge spillovers (Hsu et al., 2014). Today the development of novel technologies and their successful transfer is considered as the basic factor for national competitiveness. However, it is extensively recognized that the individual players related to science, technology and innovation (such as companies, universities, or governmental research labs) are not able to fulfil the country's innovative capacity on their own but rather need to link their strengths (Weckowska, 2014). To achieve synergy stimulating economic growth, industry and universities need fruitful collaboration. The latter can be designed by exploiting resources from both sides, meaning, commercializing technologies resulting from scientific research. This linking process is usually called technology transfer.

Modern universities are facing new challenges while meeting the social and economic requirements of current societies. The traditional way of thinking about universities as the sources of science and technology is changing (Hunady et al., 2018). In recent years, academic institutions have gone from being an arena for knowledge and technology creation to a platform for transferring them to industrial and economic spheres (Ustundag et al., 2011). Therefore, the importance of university-industry collaboration is widely emphasized in the literature (Lambert, 2003; Siegel et al., 2003b; Salter et al., 2009).

The increasing importance of technology transfer in the economy has a direct impact on national (regional) competitiveness. TTOs operating under the structure of universities are assumed as important players of innovation ecosystems. TTOs are the formal mechanisms responsible for the protection of the university-based intellectual property rights and commercialization of the inventions developed at the university (Vining \& Lips, 2015). TTOs are often considered as the key factor resulting in the success of the university or other institution (Chapple et al., 2005). Policymakers are increasingly reconsidering the activities of such offices to develop a system for TTOs to function efficiently (Curi et al., 2012). According to Siegel et al. (2003a), the main objective of TTOs is to proceed through activities such as scientific discovery, invention disclosure, evaluation of the invention for patenting, patent application, marketing of technology, negotiation of license 
and licensing to the firms. Launching of new ventures (startups or spin-offs) is also considered as a result of the technology transfer process (Tseng \& Raudensky, 2014).

Academic units are not equally successful in commercializing their knowledge (Secundo et al., 2016). The success of TTOs usually depends on various external and internal factors, such as national innovation policy, legal regulation, economic, organizational, and social factors. The majority of the research in the field is done investigating the impact of the external factors mostly related to innovation policies and regulations (Goldfarb \& Henrekson, 2003; Shane, 2004; Siegel et al., 2007). While the internal managerial factors (such as TTO strategy, cultural attitude, or developed processes) are explored less (Hulsbeck et al., 2013; Secundo et al., 2016).

Most of the studies investigating the efficiency of TTOs are focused on the assessment of the monetary key performance indicators (KPIs) (Carlsson \& Fridh, 2002; Chapple et al., 2005; Siegel et al., 2007; Kim et al., 2008; Curi et al., 2012; Vinig \& Lips, 2015), and only several studies are based on the non-monetary indicators (Thursby et al., 2001; Secundo \& Elia, 2014). However, according to Granieri and Frederick (2013), these indicators do not reflect the performance of TTOs - they just reveal the level at which the organization's performance is at a certain moment. Thus, in order to achieve a more comprehensive view of the performance of TTOs, the factors influencing it have to be identified and investigated. Various scholars have been studying such factors so far (Ustundag et al., 2011; Caldera \& Debande, 2010; Chapple et al., 2005; Hulsbeck et al., 2013), though, there is a lack of more complex comparative studies investigating their reasoning in more diverse samples.

A complex view of the factors influencing TTO's performance would allow improving TTO's management decision making, increasing their productivity, and supporting more target-oriented national innovation policies. To understand the broader and more varied perspective of the issue, the cross-country research implying the reasoning of the factors influencing the performance of TTOs based in Europe would be relevant. The context of the European Consortium of Innovative Universities (ECIU) serves as a good sample for such research.

This study aims to reason factors influencing the performance of TTOs at the members of ECIU as research and technology transfer oriented universities. Even though each TTO has its own organizational peculiarities, universities belonging to ECIU are considered to be as related through their innovation policies. It is obvious that all ECIU members have their institutional uniqueness and differences that might have an influence on the research results of the broader scope studies among the universities. However, joint initiatives of action among ECIU partners encourage consolidation and serve as a good reference point for research.

The study focuses mostly on the internal managerial factors, as less investigated and having a higher potential for managerial exposure. It starts with the literature review on the factors influencing TTO's performance. The research methodology enabling identification of the key managerial factors influencing the performance of TTOs at the ECIU network is argued afterwards. While reasoning of the identified factors and discussion are provided at the end of the study.

Identification of the factors influencing the performance of TTOs at ECIU members is important not only for revealing technology transfer trends among innovative European universities, but also for detecting the best practices in the ECIU network, sharing experience, and developing synergy-oriented policymaking. There is no target to have unified solutions among ECIU members, however, understanding such factors and learning from the best practices would be beneficial for all partners.

\section{Literature Review}

Different definitions of a TTO and its role in the socio-economic context are observed in the literature so far. Some of them are formulated on a more philosophical level and mostly focus on the added value (Carlsson \& Frith, 2002; Siegel et al., 2003a; Tahvanainen \& Hermans, 2011; York, 2012; Lafuente et al., 2017), the others emphasize the functionality of these entities (Anderson et al., 2007; Ustundag et al., 2011; Hulsbeck et al., 2013; Weckowska, 2014; Vining \& Lips, 2015). However, summarizing them, the following definition can be outlined as applicable within this study: By recognizing potentially commercializable inventions and identifying licensees and/or investors for them, the Technology Transfer Office is an intermediary between academia and industry, ensuring resources for the development and exploitation of the university's intellectual property.

To assess the performance of TTOs, scholars mostly distinguish different monetary and non-monetary KPIs, such as a number of license agreements, licensing income, number of spin-offs and startups, number and value of R\&D contracts, filed patents, inventions disclosed or similar (Lee \& Bray, 2000; Thursby \& Thursby, 2002; Chapple et al., 2005; Anderson et al., 2007; Siegel et al., 2007; Kim et al., 2008; Caldera \& Debande, 2010; Ustundag, Ugurlu \& Kilinc, 2011; Curi, Daraio \& Llerena, 2012). These metrics measure the results of the activities of TTOs and identify at what level TTOs are performing. However, they do not reveal how TTOs could upgrade their activities to improve performance. TTOs are influenced by different external factors (that are beyond the control of the TTO), such as political regulation or economic uncertainty, as well as internal ones (that are controlled by the TTO), such as IP management issues, human resource management practices, or strategic priorities of TTOs. For instance, a clear university's strategy developed and communicated among scientists and TTO enables more efficient collaboration between TTO and academic community and makes impact on TTO's performance. Or, if a decision to manage a licensing portfolio is made, training and development of TTO's personnel are required accordingly (Chapple et al., 2005) which is most likely to have an influence on TTO performance. Such and similar factors are getting even more relevant in the TTO value creation process.

Different perspectives regarding the factors influencing the performance of TTOs have been studied in the literature so far. Markman et al. (2005) developed a 
model to identify the links between TTO structures, new ventures, and licensing strategies. Based on it the authors revealed that a shorter commercialization process could positively influence the performance of TTO, while the expertise of the personnel could have a positive impact on assessing licensing processes professionally. Meanwhile, other scholars (Friedman \& Silberman, 2003; Caldera \& Debande, 2010) in their research were focusing on a clear mission and objectives, location, and organizational structure of TTO.

Santoro and Gopalakrishnan (2000) found out that companies with a more mechanistic structure, stabilityoriented culture, and trust in universities as partners, were more likely to establish knowledge transfer activities. They also indicated trust as the main variable for the evaluation of knowledge transfer activities. According to them, knowledge creation requires new ideas, that must be integrated, combined with existing knowledge, and seen from a new perspective crossing the boundaries of organizations. Furthermore, the appropriate culture of an organization enables to facilitate the external knowledge for improving the quality and quantity of task-related activities. York and Ahn (2012) supplemented the latter conclusion by systematically comparing successful and less successful TTOs in order to indicate the factors that lead to the success of TTOs owned by the universities. In their study they compared the cases based on the following dimensions: i) age and size; ii) business strategy/marketing; iii) intellectual property protection; iv) performance benchmarking; v) revenue generation focus; vi) business stakeholder relationships; vii) institutional support; viii) project structure; and ix) internal as well as external website utilities.

Empirical quantitative and qualitative research conducted by Siegel et al. (2003a) revealed a set of groups of internal, environmental, institutional, and organizational factors that influence the performance of TTOs. According to the authors, the most important factors are the following: i) reward system at the faculty; ii) compensation on staff; iii) TTO's ability to destroy cultural barriers between universities and business.

Frederick and Granieri (2016) in their study validating the business growth $\mathrm{CCODE}^{1}$ model identified 28 influential factors. The study conducted by these scholars highlighted several new factors influencing the performance of TTOs, such as: i) tools and methodologies applied; ii) the scale and absorptive capacity of customer base; iii) IP quality and market relevance; iv) knowledge generation capacity; v) TTO - IP creator desire; and vi) proximity to the market.

Even though there is a significant number of studies conducted on the factors influencing the performance of TTOs so far, they have been discussed in the literature in a very fragmentary way. Furthermore, as will be disclosed further in the study, there has been no clear distinction, which set of factors would be applicable for management decision-making at TTOs in the European context.

\footnotetext{
${ }^{1}$ CCODE is a tool developed by Pera Consulting, which states that all organizations pass through a series of stages in their life cycle.
}

Thus, based on the systematic literature review performed and the trends identified, six groups of factors were distinguished as meaningful for further investigation within this study (see Table 1): i) IP strategy and policy; ii) organizational design and structure; iii) human capital; iv) relationships with industry; v) economic incentives; and vi) cultural aspects.

The factors classified as the group IP strategy and policy concentrate on the matters related to intellectual property rights (IPR) and their management as well as on the support for TTO provided by the university on a strategic level. For example, as pointed out in the study carried out by Siegel et al. (2003a), objectives set up for TTOs need to be consistent with existing organizational policies. These issues are important as they contribute significantly or reduce the output of technology transfer at the university, or even push academics to look for other alternatives of the commercialization of their knowledge.

The group of factors Organizational design and structure is about the structure of TTOs. Mostly TTOs are structured in different models varying in their size, age, experience, etc. Different studies reveal that these factors have an impact on the performance of TTOs. For instance, it is frequently assumed in the literature that the level of the support given to TTOs by the administration of the universities, the experience of TTOs or the level of the freedom of action contributes to the productivity of TTOs and facilitates technology transfer (Friedman \& Silberman, 2003; Siegel et al., 2003a; Carlsson \& Frith, 2002; Curi et al., 2012; Fai et al., 2018).

The latter group of factors is closely related to the one focused on Human capital as depending on what kind of background and expertise is required for the personnel of TTO, what conditions are created for improving their qualification, how long it takes to achieve positive results, etc. Business skills and understanding of how the value is created at TTOs are crucial (Siegel et al., 2003a). However, some studies reveal that a balanced skill-set of managers, scientists, and lawyers is required for the efficient moving forward of TTOs (Cjasinkskiampbell, 2007; Lafuente \& Berbegal-Mirabent, 2017).

Relationships with industry represents the awareness of industry needs and the importance of networking through interactions between scientists and companies. As, for example, confirmed by key respondents in Villani's et al. (2017) study, strong and wide networks mitigate problems in university-industry collaboration, enhancing the likelihood of success. A deep understanding of the needs of industries as well as trust and connectedness between industrial firms and research centers are crucial here.

The group Economic incentives are about the financial situation and internal/external support for TTOs as well as for the actors in the relevant innovation ecosystem. Institutional support, industrial agglomerations or the private spending on R\&D play a supportive role in technology transfer (Curi et al., 2012). Understanding these incentives and related issues should be addressed for a positive impact. 
Ruta Zmuidzinaite, Sandra Zalgeviciene, Lina Uziene. Factors Influencing the Performance of Technology Transfer ...

Table 1

Factors Influencing the Performance of TTOs

\begin{tabular}{|c|c|c|}
\hline $\begin{array}{l}\text { Group of } \\
\text { factors }\end{array}$ & Factors & Researchers \\
\hline $\begin{array}{l}\text { IP strategy } \\
\text { and policy }\end{array}$ & $\begin{array}{l}\text {-University policies; } \\
\text {-Bureaucracy; } \\
\text {-The impact of rewards for faculty involvement in technology } \\
\text { transfer; } \\
\text {-Clear mission and objectives; } \\
\text {-University technology transfer - intellectual property policies. }\end{array}$ & $\begin{array}{l}\text { Caldera A. \& Debande O. (2010); Siegel D. et } \\
\text { al. (2003a); Lach S. \& Schankerman M. (2004); } \\
\text { Debackere K. \& Veugelers R. (2005); Santoro } \\
\text { M. D. \& Bierly P. E. (2006); Kruss G. \& Visser } \\
\text { M. (2017); Fai, F., M. et al. (2018). }\end{array}$ \\
\hline $\begin{array}{l}\text { Organization } \\
\text { al design and } \\
\text { structure }\end{array}$ & $\begin{array}{l}\text {-Public versus private; } \\
\text {-Presence of a medical school; } \\
\text {-Organizational structure and operational processes/policies of } \\
\text { TTO; } \\
\text {-The level of authority and support given to TTO in the } \\
\text { university administration; } \\
\text {-University organizational forms; } \\
\text {-Participation of faculty in the licensing process; } \\
\text {-The experience of TTO; } \\
\text {-The presence of a science park; } \\
\text {-The size of TTO. }\end{array}$ & $\begin{array}{l}\text { Anderson T. R. et al. (2007); Friedman J. \& } \\
\text { Silberman J. (2003), Siegel, D.S. et al. (2003a); } \\
\text { Secundo G. et al. (2016); Carlsson B. \& Frith } \\
\text { A. (2002); Thursby J. G. et al. (2001); Curi C. } \\
\text { et al. (2012); de Beer C. et al. (2017); Fai F., } \\
\text { M. et al. (2018). }\end{array}$ \\
\hline $\begin{array}{l}\text { Human } \\
\text { capital }\end{array}$ & $\begin{array}{l}\text {-TTO competency in identifying licenses; } \\
\text {-TTO staffing/compensation practices; } \\
\text {-A balanced skill-set of managers, scientists and lawyers within } \\
\text { TTO personnel; } \\
\text {-Business skills and management capabilities at TTO. }\end{array}$ & $\begin{array}{l}\text { Markman G. D. et al. (2005); Chapple W. et al. } \\
\text { (2005); Libecap G. (2005); Kim J., Anderson } \\
\text { T., \& Daim T. (2008); Lafuente E. \& Berbegal- } \\
\text { Mirabent J. (2017). }\end{array}$ \\
\hline $\begin{array}{l}\text { Relationships } \\
\text { with industry }\end{array}$ & $\begin{array}{l}\text {-The amalgamation of solid technical expertise and extensive } \\
\text { industrial experience in the individual licensing officer; } \\
\text {-TTO understands the needs of industry; } \\
\text {-The influence of innovation networks on the dynamics of the } \\
\text { technology transfer; } \\
\text {-Social connectedness and trust between industrial firms and } \\
\text { university research centers. }\end{array}$ & $\begin{array}{l}\text { Tahvanainen A.J. \& Hermans R (2011); } \\
\text { Hulsbeck M. et al. (2013); Perez M. \& Sanchez } \\
\text { A. M. (2003); Libecap G. (2005); Frederick \& } \\
\text { Granieri (2015); York A. S. \& Ahn M. J. } \\
\text { (2012); Santoro M. D. \& Bierly P. E. (2006); de } \\
\text { Beer C. et al. (2017); Villani, E. et al. (2017). }\end{array}$ \\
\hline $\begin{array}{l}\text { Economic } \\
\text { incentives }\end{array}$ & $\begin{array}{l}\text {-Regional concentrations of venture capital and high technology; } \\
\text {-The level of priority and support given to higher education in a } \\
\text { community or region; } \\
\text {-Location of TTO; } \\
\text {-GDP per capita; } \\
\text {-Industrial agglomeration; } \\
\text {-Private spending on R\&D; } \\
\text {-Government support. }\end{array}$ & $\begin{array}{l}\text { Foltz J. et al. (2000); Chapple W. et al. (2005); } \\
\text { Anderson T. R., et al. (2007); Ustundag A. et } \\
\text { al. (2011); Curi et al. (2012); York A. S. \& Ahn } \\
\text { M. J. (2012); Frederick P. \& Granieri M. } \\
\text { (2015). }\end{array}$ \\
\hline $\begin{array}{l}\text { Cultural } \\
\text { aspects }\end{array}$ & $\begin{array}{l}\text {-Cultural barriers between universities and firms; } \\
\text {-Cultural differences between the academic and the commercial } \\
\text { domains; } \\
\text {-R\&D institutions not fully open or prepared to cooperate with } \\
\text { firms; } \\
\text {-Innovative culture and mentality among employees; } \\
\text {-Institutional support to scientists for involvement in technology } \\
\text { transfer process; } \\
\text {-Expanded institutional alignment factor. }\end{array}$ & $\begin{array}{l}\text { Siegel et al. (2003b); Siegel et al. (2004); Plewa } \\
\text { et al. (2006); Campbell (2007); Jasinski (2009); } \\
\text { Harman (2010); York \& Ahn (2012); Villani, } \\
\text { E. et al. (2017). }\end{array}$ \\
\hline
\end{tabular}

And last but not least group of factors - Cultural aspects - includes the mindset concept of the different actors involved in the technology transfer process. Some cultural differences or barriers between academia and commercial domains (Siegel et al., 2003b; Jasinski, 2009; Villani et al., 2017), mentality of the staff of TTO or support to scientists for involvement in technology transfer process (Plewa et al., 2006; Campbell, 2007) have an impact on the performance of TTOs and require attention.

Following available literature on technology (knowledge) transfer and the performance of TTOs it is evident that so far most of it has been concentrated exceptionally on the cases in the U.S. (Shane, 2004; Thursby \& Kemp, 2002; Thursby \& Thursby, 2002; Siegel, Waldman \& Link, 2003; Lockett \& Wright, 2005;
Anderson, Daim \& Lavoie, 2007; Kim, Anderson \& Daim, 2008; Heisey \& Adelman, 2011; Tahvanainen \& Hermans, 2011; York, 2012; Tseng \& Raudensky, 2014), the UK (Lockett, Wright \& Franklin, 2003; Chapple et al., 2005; Meyer \& Tang, 2007; Siegel et al., 2008; Kamariah et al., 2011) and Italy (Balderi et al., 2007; Fini, Grimaldi, \& Sobrero, 2009; Muscio, 2010; Fini et al., 2017; Algieri, Aquino \& Succurro, 2013). The concept of TTO was developed in the U.S., thus it is consequential that most of the studies are conducted in this context. Meanwhile, other countries have been investigated only by several studies and very fragmentedly. For instance, researches related to Spanish and German cases were conducted by del BarrioCastro and Garcia-Quevedo (2009), Caldera and Debande (2010), and Hulsbeck, Lehmann and Starnecker (2013), 
Buenstorf and Geissler (2012), as well as some studies conducted in the context of Belgium (Debackere \& Veugelers, 2005), Canada (Bathelt, Kogler \& Munro, 2010), Denmark (Baldini, 2006), Sweden (Nilsson, Rickne \& Bengtsson, 2010), the Netherlands (Vinig \& Lips, 2015), and France (Curi, Daraio \& Llerena, 2012).

The mentioned studies are mainly conducted in one of the countries, regions, cities, or universities. Only several cross-country comparative studies on the performance of TTOs have been done so far: the U.S. and Canadian case on contrasting the number and type of spinoffs produced by the universities in these countries (Kenney \& Patton, 2001); university patenting situation in Germany and Sweden (Sellenthin, 2009); Portuguese and Spanish case on royalty sharing, effort and invention at the universities (Arque-Castells et al., 2016); and a longitudinal, multilevel study on institutional determinants of university spin-off quantity and quality in Italy, Norway and the UK (Fini et al., 2017).

Thus, to the best of our knowledge at the time of this study conduction, there had not been cross-country studies conducted on the reasoning of the factors influencing the performance of TTOs on a larger scale. Therefore, summarizing the literature review it can be outlined that this study contributes to filling in the following gaps in the literature related to the factors influencing the performance of TTOs:

- a lack of research conducting a comparison among factors influencing the performance of TTOs belonging to the universities;

- the performance of TTOs of European countries is studied much less than the American one;

- a lack of comparative cross-country research;

- very few studies have classified the factors influencing the performance of TTOs according to subject similarity so far.

\section{Research Methodology}

Two research methods were applied when carrying out the empirical study (see Table 2). The survey was employed in the initial stage of the study with the purpose to grasp subjective views of the representatives of TTOs on the factors influencing the performance of TTOs. While in the later stage, semi-structured interviews with the leaders of the TTOs were conducted to receive a deeper contextual understanding and reason the identified factors. This study was carried out in 2018 and was a part of a larger-scale research.

The final sample of the study consisted of 10 member universities (out of $12^{2}$ ) in the case of survey and 6 (out of 12 ) in the case of semi-structured interviews of the European Consortium of Innovative Universities (ECIU). ECIU context was relevant for this research because of several reasons. Firstly, all universities belonging to the

\footnotetext{
${ }^{2}$ Kaunas University of Technology, Aalborg University, Dublin City University, Hamburg University of Technology, Linköping University, Tampere University of Technology, Tecnológico de Monterrey, The University of Nottingham, Universitat Autònoma de Barcelona, University of Aveiro, University of Stavanger and University of Twente.
}

ECIU consortium were oriented to innovation and entrepreneurship, and therefore, issues of the technology transfer were the key on their priority list. Secondly, peerto-peer learning was perceived as effective, thus, it was beneficial to share different approaches to similar situations among members and to possibly learn from the best practice. Thirdly, all these universities had actively operating TTOs.

While starting the empirical research, the survey was carried out as an initial point of investigation. The purpose of the survey was to indicate the main factors influencing the performance of TTOs, based on the opinions of the representatives of ECIU TTOs. The survey consisted of the suggested groups of factors, the importance of which the respondents had to evaluate using the Likert scale: 1 meant "has no impact", while 5 - "has major impact". Based on the assessment results, the factors defined as important in the literature review phase were empirically assessed accordingly to their importance on the selected scale.

Based on the results of the survey as well as the findings of the literature review, semi-structured interviews with 6 leaders of ECIU TTOs were conducted, which provided deeper contextual understanding and enabled reasoning of the factors influencing the performance of TTOs in a cross-university European context.

The questions of the semi-structured interviews (see Table 2) were directed at the deeper clarification and reasoning of the influencing factors, which provided a deeper understanding of the origin and effects of the factors. Transcribed interviews' texts were processed with qualitative content analysis. The latter was applied by reading the text repeatedly, coding it into categories and subcategories, interpreting, and identifying logical interfaces among them. During the categorization the text was systematized and reframed according the meaningful semantic units. The supporting quotes for each subcategory were selected. The end result of the qualitative content analysis was a single categorization system for all transcribed texts that would allow a subsequent comparison of the data, which would be in line with the categorization of factors envisaged at the beginning of the study, thus allowing conclusions to be drawn that are consistent with the main purpose of the study. The ethical issues were assessed while transcribing the texts, i.e. the aim was to ensure that the information obtained in the course of the investigation does not cause any conflict of interest and that it does not compromise, injure or otherwise violate the privacy of the individuals mentioned in the interview.

The combination of the applied methods and step-bystep research approach enabled consistent reasoning of the factors and ensured their broad contextual coverage as well as the depth of this research.

\section{Study Results}

The empirical study revealed differences and similarities among the TTOs of ECIU members. It was revealed that TTOs with a longer period of existence perform more successfully than the newly established ones. However, the issues they are challenged with are 
Ruta Zmuidzinaite, Sandra Zalgeviciene, Lina Uziene. Factors Influencing the Performance of Technology Transfer ...

rather similar. The key difference is that the longer existing TTOs have gained more experience over the years, and thus has leverage in how to deal with certain challenges in an effective way. Meanwhile, the younger TTOs are not there so far, and therefore, learning from good practices is essential for them. Yet, the factors influencing the performance of TTOs are almost identical despite the age of TTO. Furthermore, the same trend can be applied to the aspect of a country of establishment: there are no significant differences among different countries regarding factors influencing the performance of TTOs operating there.

Table 2

Framework of the Research Methodology

\begin{tabular}{|c|c|c|c|}
\hline \multirow{2}{*}{$\begin{array}{l}\text { Group of } \\
\text { factors }\end{array}$} & \multicolumn{2}{|c|}{ Factors involved in the survey } & \multirow{2}{*}{$\begin{array}{c}\text { Guiding questions of the semi- } \\
\text { structured interviews }\end{array}$} \\
\hline & Factors & Supporting studies & \\
\hline $\begin{array}{l}\text { IP strategy and } \\
\text { policy }\end{array}$ & $\begin{array}{l}\text { - clear TTO strategy with the action } \\
\text { plan; } \\
\text { - awareness of the University's } \\
\text { scientific key points; } \\
\text { - functioning and effective system of } \\
\text { KPIs at TTO. }\end{array}$ & $\begin{array}{l}\text { Lockett et al. (2003); Friedman } \\
\& \text { Silberman (2003); Rasmussen } \\
\text { et al. (2006); Caldera \& } \\
\text { Debande (2010); Graham } \\
\text { (2013). }\end{array}$ & $\begin{array}{l}\text { - Who owns the IP rights at your } \\
\text { University? } \\
\text { - Does your TTO have a strategy? If } \\
\text { yes, what is the main purpose of it? } \\
\text { - How do you measure the } \\
\text { performance of your TTO annually? }\end{array}$ \\
\hline $\begin{array}{l}\text { Organizational } \\
\text { design and } \\
\text { structure }\end{array}$ & $\begin{array}{l}\text { - period of employment at TTO; } \\
\text { - quality of process management at } \\
\text { TTO }\end{array}$ & $\begin{array}{l}\text { Siegel et al. (2003a); Markman } \\
\text { et al. (2005); Caldera \& } \\
\text { Debande } \quad(2010) ; \quad \text { Secundo } \\
\text { (2016). }\end{array}$ & $\begin{array}{l}\text { - Introduce the structure of your TTO. } \\
\text { - Could you define what part of the } \\
\text { work at your TTO is devoted } \\
\text { separately to students, scientists and } \\
\text { companies? }\end{array}$ \\
\hline Human capital & $\begin{array}{l}\text { - proactive and motivated TTO staff; } \\
\text { - business experience of TTO staff; } \\
\text { - possibilities to improve the } \\
\text { qualification of TTO staff according } \\
\text { to their needs. }\end{array}$ & $\begin{array}{l}\text { Siegel et al. (2003b); Markman } \\
\text { et al. (2005); Chapple et al. } \\
\text { (2005); Balderi et al. (2007). }\end{array}$ & $\begin{array}{l}\text { - Introduce the backgrounds of } \\
\text { yourself and your employees. } \\
\text { - Is there any motivational system } \\
\text { functioning in your TTO? If yes, } \\
\text { what kind? } \\
\text { - What kind of training activities do } \\
\text { your employees receive? } \\
\text { - Do you agree that business } \\
\text { experience possessed by employee is } \\
\text { more important while working at the } \\
\text { TTO than the year spent at the TTO? } \\
\text { Please, elaborate. }\end{array}$ \\
\hline $\begin{array}{l}\text { Relationships } \\
\text { with industry }\end{array}$ & $\begin{array}{l}\text { - effective and regular TTO marketing } \\
\text { campaign; } \\
\text { - face-to-face contacts between TTO } \\
\text { and industry; } \\
\text { - matchmaking events; } \\
\text { - active scientific service marketing } \\
\text { provided by researchers of the } \\
\text { University. }\end{array}$ & $\begin{array}{l}\text { Tahvanainen \& Hermans } \\
\text { (2011); Hulsbeck et al. (2013). }\end{array}$ & $\begin{array}{l}\text { - How do you reach the industry or } \\
\text { does the industry reach your TTO? } \\
\text { - How is the participation of your } \\
\text { TTO in the international events } \\
\text { organized? }\end{array}$ \\
\hline $\begin{array}{l}\text { Economic } \\
\text { incentives }\end{array}$ & $\begin{array}{l}\text { A set of the following quantitative KPIs } \\
\text { was monitored among the members } \\
\text { during the study period instead of the } \\
\text { factors surveyed: } \\
\text { - invention disclosures to the TTO; } \\
\text { - patents gained with any kind of } \\
\text { TTO's assistance; } \\
\text { - spin-offs; } \\
\text { - start-ups; } \\
\text { - university-industry joint research } \\
\text { projects; from university-industry } \\
\text { - revenues from for } \\
\text { joint research projects; } \\
\text { - revenues from licensing; } \\
\text { - revenues from consultations for } \\
\text { enterprises, etc. }\end{array}$ & $\begin{array}{l}\text { Siegel et al. (2003a); Anderson } \\
\text { et al. (2007); Thursby \& } \\
\text { Thursby (2002); Kim et al. } \\
\text { (2008); Siegel et al. (2007); } \\
\text { Chapple et al. (2005); Caldera \& } \\
\text { Debande (2010); Ustundag et al. } \\
\text { (2011) }\end{array}$ & $\begin{array}{l}\text { - How does the financing for the start- } \\
\text { ups and spin-offs operate in your } \\
\text { case? }\end{array}$ \\
\hline $\begin{array}{l}\text { Cultural } \\
\text { aspects }\end{array}$ & $\begin{array}{l}\text { - informal relations and friendly } \\
\text { atmosphere at the University; } \\
\text { - early stage disclosures of invention to } \\
\text { TTO; } \\
\text { - inventions disclosed by researchers. }\end{array}$ & $\begin{array}{l}\text { Siegel et al. (2003); Siegel et al. } \\
\text { (2004); Jasinsk (2009); Harman } \\
(2010) \text {. }\end{array}$ & $\begin{array}{l}\text { - How does your TTO encourage the } \\
\text { disclosures of inventions? } \\
\text { - How do the informal relations reflect } \\
\text { in your work? }\end{array}$ \\
\hline
\end{tabular}

Based on the results of the statistical analysis of the survey, it was revealed that the respondents gave the highest scores to the following impact factors: i) proactive and motivated TTO staff; ii) business experience of TTO staff; iii) clear TTO strategy with the action plan; iv) faceto-face contacts between TTO and industry; v) informal relations and friendly atmosphere at the University; as well as vi) matchmaking events (see Figure 1). 


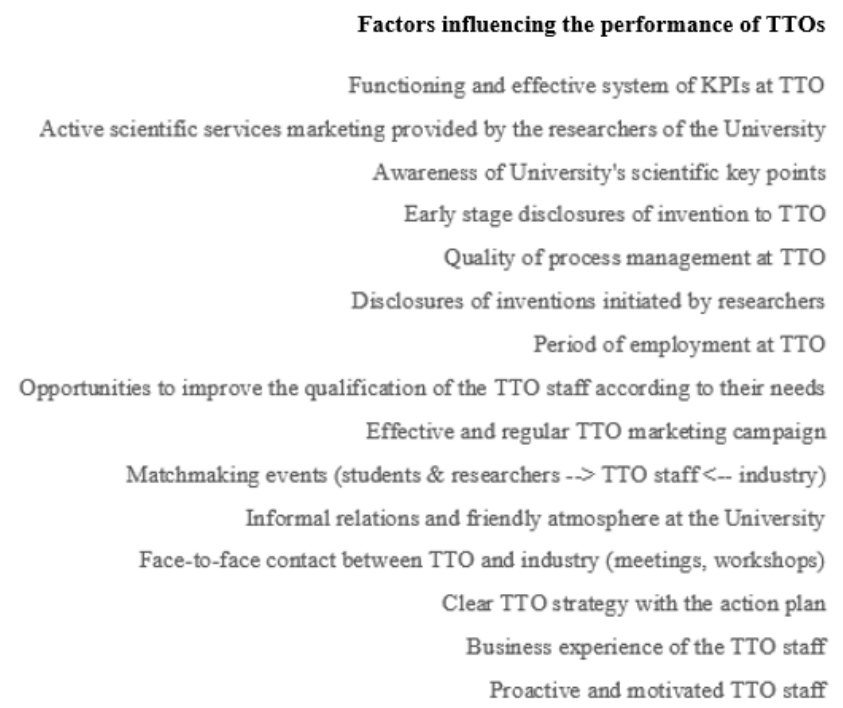

Factors influencing the performance of TTOs

Average evaluation on Likert scale for each factor

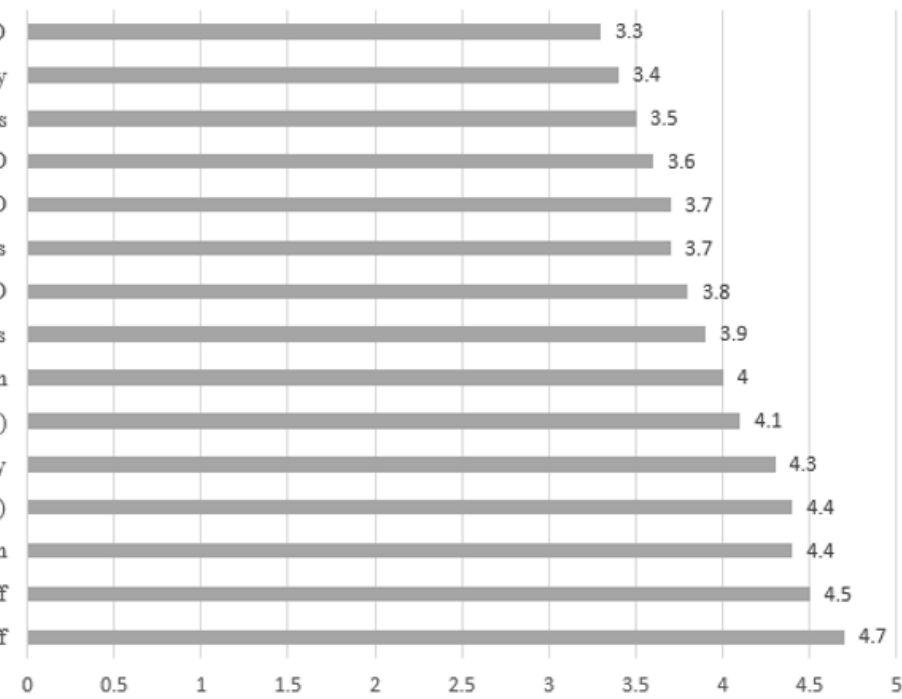

Figure 1. Factors influencing the performance of TTOs of ECIU members

Two leading factors among all suggested - clear TTO strategy and proactive and motivated TTO staff - were qualified as the most important. They are related to IP strategy and policy issues as well as the human capital category, which is highly emphasized as important in the literature (Markman et al., 2005; Friedman \& Silberman, 2003; Chapple et al., 2005; Secundo et al., 2016). Informal relations at the university, face-to-face contact between TTO and industry, matchmaking events as well as effective TTO marketing were qualified as slightly less important, however, meaningful. Factors such as staff training, period employed at TTO, early-stage disclosures of invention, disclosures of inventions initiated by researchers as well as the quality of process management at TTO were treated as moderately important. Meanwhile, factors such as marketing of scientific services, awareness of the University's key scientific points, and KPIs system functioning at the TTO were qualified as the least important. The position of different TTOs among the ECIU members in regard to the key influencing factors was quite similar. While more detailed conclusions and generalizations here would only be possible if to enlarge the survey sample.

Analyzing the results of the survey, it was observed that in the case of TTOs some common business management principles are valid: to have higher TTO performance, a clear strategy is required and the principle "put people first" has to be followed. Meanwhile, such factors as well structured KPIs system or smooth business process management are perceived as natural and obligatory.

Deeper contextual knowledge regarding TTOs' performance acquired from the findings of the semistructured interviews highlighted the following aspects as having the most influence on the performance of TTOs at the ECIU network: i) relationships with investors; ii) functioning of a special TTO unit dedicated to working with industry; iii) business experience of TTO staff; iv) networking; and v) TTO strategy. The reasoning of these factors is discussed further.
Not surprisingly, financing from investors and relationship with them were identified as dominating factors for TTO's activities. The interviewees provided various arguments regarding this issue, however, all of them claimed that without financial stability there are no opportunities to develop new technologies and to increase the quality of research work. To add, most of the external funding usually comes to TTOs from private funds, such as business angels or venture capital. Some respondents identified that for the development of their internal technologies, they gather the consortium of investors by using their networks, and this helps to make prospective investments for future technologies. Some of them stated that there are many early-stage investors in their country, who are willing to take a risk as they are led by curiosity, personal interests, and prestige. In other cases, funding from regional SMEs (small and medium enterprises) and multinational companies was mentioned. However, despite the variety of funding sources, based on the analysis of different statements of interviewees, it can be argued that private funding and relationships with investors are critical for the effective performance of TTOs.

One more important factor is relationships with industries. There are many ways of how to start and extend cross-sectoral collaboration. One of them is the establishment of a separate unit within the TTO's structure, which would be responsible for the communication with the industry in the region. Another way is to have a staff member who is responsible for liaison with the companies. Management of the latter depends on what strategy TTO is following, in other words, what the general focus of TTO's activities is. For example, one of the interviewed TTOs does not have an IP portfolio because there are no resources such as business developers who could commercialize patented technologies and search for licensing opportunities. Therefore, this TTO focuses on joint research projects with the industry, and, compared to the others, it has the largest number of research and development $(R \& D)$ contracts between the researchers and 
the companies. Meanwhile, the rest of the TTOs were represented as focusing on bringing technologies to the market by licensing or establishing spin-offs. Nevertheless, industry liaison is a must because it is essential to know what the needs of the industries are and what challenges they face. In one of the cases investigated, the TTO provided services for the whole region while the municipality was one of the shareholders of the office. This TTO had the role of a linkage on the regional level, and hence the industry was stimulated to collaborate with it on a continuous basis. The practical examples mentioned above illustrate one more important factor for TTO's performance - the strategic focus of TTO, which among many other aspects sets the path for the relations, influencing the achievements of TTO on a broader scale.

To continue, to achieve the goals of any TTO, specific staff competencies are crucial. All the interviewed representatives confirmed that the business experience of staff members is one of the most important factors influencing the performance of TTOs. This competence is vital because the technology transfer process is consisting of many aspects, which are business development-oriented, and therefore, a person experienced in business development is of much value to any TTO. Moreover, it was specified by the representatives from some TTOs that in particular having economic skills allows evaluating the inventions on the realistic scale, in this way avoiding, for instance, misjudgment in expected revenues. To add, due to the possibility of more creative and original outcomes the interviewees also mentioned diversity of people possessing different professional backgrounds as an adding value for the team working at TTO.

The business experience and economic skills are closely related to one more significant factor influencing the performance of TTOs - networking. All interviewees explained that being a part of the network in the region is critical to successfully mediate between science and industry. Organizing and participating in the matchmaking events, exhibitions, innovation clubs, workshops, and seminars is just one of the ways to establish new contacts and to stay close to the enterprises as well as to the members of the university. While establishing personal networks based on trust and respect is the core of every solid TTO.

So, semi-structured interviews with the leaders revealed relationships with investors and industries, networking activities, developed strategy, and business experience of TTO staff as the most important for TTO's performance. Meanwhile, factors such as the TTO KPIs system or process management activities, the same way as in the case of the survey, were treated as natural and less important.

\section{Discussion and Guidelines for Further Research}

Several points related to the factors influencing the performance of TTOs, which were highlighted based on the summarized results of the survey and the semistructured interviews, can be brought up for discussion leading to further investigations.

Firstly, considering TTO's structure several models of TTOs exist in practice, such as i) TTO operating within a university; ii) external holding company owned by university; iii) combination of internal and external TTO; iv) external services bought by university in order to perform TTO function; v) external TTO with a university(ies), a municipality(-ies), and other (if any) stakeholders as shareholders (Campbell, 2007). Depending on many arguments and conditions, universities choose which model is the most applicable for their current situation. According to the interviewees of this study, internal TTOs cannot generate revenues from consultations or events for the companies while external TTOs cannot be fully financed from such programs as Horizon 2020 because such type of TTOs are for-profit companies and the intensity of the projects covered by this European program for them is only $70 \%$. While having an internal and external TTO can be convenient but at the same time confusing because of the division of tasks.

Secondly, even though the relationships with investors for the performance of TTO were emphasized during the semi-structured interviews with the leaders, there are different opinions and perspectives regarding the involvement of investors in the process of the creation of new technologies. One of the attitudes expressed during the interviews, was that as soon as external financing is involved, the creator of an invention loses control of the project, and therefore, conflict of interests starts. However, an opposite viewpoint exists as well, which argues that without any financial resources new knowledge cannot be developed, and usually, if investors support one project it means that it has real potential and so it is worth an investment (Curi et al., 2012). Most of the time venture capitalists are not willing to invest in the projects which are solely based on ideas and have no reasoning (for example, a prototype or research data results). According to the interviewed leaders, the willingness to take such risks must come from personal interests, and thus it is more related to cultural mindset and traditions developed over time in the region.

Thirdly, there is a wide discussion in regard to what expertise is needed for the employees of a TTO (Siegel et al., 2003a; Cjasinkskiampbell, 2007; Lafuente \& BerbegalMirabent, 2017). As indicated in Siegel et al. (2003b) research, when it comes to recruiting, TTOs usually look for expertise in patent law and licensing or technical competencies, and not so often for individuals with marketing skills. The authors conclude that universities should hire personnel for TTO work with more significant business experience. The same attitude was also confirmed by the interviewees of this study. Yet, they emphasize that it does not necessarily mean the experience of working at a company or getting an MBA. It is more about having a real economic sense and being able to evaluate the actual potential of technology and market as well as to effectively assist in developing the inventions created by the researchers. Technology transfer specialists are operating in a process of sales; but, according to the interviewed leaders, these types of sales are not typical because during the technology transfer process both sides need to be taken care of - one of the sellers as much as one of the customer. Ideally, it can be concluded that a perfect employee should have a mixed background, for instance, technological education and experience in owning or running a start-up. 
Unfortunately, that is not a common case; therefore, it can be suggested that any TTO should have a strategy for employment and human resource development, meaning, that if a staff member lacks certain skills there are conditions for him or her to gain those lacking competences through, for instance, training courses, practical learning, colleagues, etc. Moreover, selfevaluation could be used as one of the tools to assess existing knowledge at TTO and to utilize it at maximum on the organizational level.

Fourthly, as one of TTOs' functions is to bridge the gap between science and industry (Siegel et al., 2007), it was confirmed by the interviewees that it is essential to take part in networking activities inside and outside the university. Therefore, effective communication takes a crucial role in cross-sectoral collaboration, and trust is a key factor to achieve it. However, depending on the model of the TTO, some of them have the whole unit working directly and actively with the industry, some have a person responsible for the communication with the companies, and in some, all staff members are encouraged to get in contact with the industry in one or another way. Despite the structural arrangements, direct and indirect contacts between researchers and enterprises are in the spotlight of any TTO. It is also closely related to the background and skills of the TTO staff because those, who are entrepreneurs and are employed already having business experience, bring to the TTO their industrial knowledge and personal social capital. In such a way, they represent the science community and the business world at the same time. Yet, being recognized by those two worlds takes time as gaining confidence is a constant and demanding process.

Finally, based on the interviews with the leaders of TTOs as well as the literature review, it is considered that technology transfer should generate revenues. For that reason, most of the studies so far has been focusing on evaluating performance of TTOs through monetary KPIs. However, as this study revealed, such assessment should reflect many more aspects than only monetary ones. For instance, the leaders of TTOs at ECIU claim that societal benefits should be valued more than revenues for one unit within society. Knowledge transfer is a long and specific process requiring constant effort from internal and external actors towards the result. For example, one of the interviewees argued that it can take up to two years to establish a spin-off based on new technology, and it involves such processes as coaching the CEO, finding investors, filing in patent application, establishing partnerships, etc. For this reason, while assessing their performance the TTOs should consider an option to conduct more detailed qualitative evaluations along with the quantitative ones. Furthermore, strategic focus is what sets the direction towards certain goals. Therefore, according to the interviewees, it is significant to evaluate the strengths and weaknesses of the university to distinguish which areas are worth focusing on in regard to the commercialization of technologies. Based on that, the IP portfolio should be built up only for those inventions which have high potential to be brought to the market. And of course, the relevant legislative system should be prepared for the creation of spin-offs within the universities.
Following these discussion points and thinking of further research it is highly recommended that the results of this study would be tested on a larger number of TTOs, as this would allow more objective generalization of the findings of this research. Moreover, this study could be successfully enlarged involving more aspects. Since the study adds to the so far limited cross-country analyses of the influential factors, further recommended studies could be carried out with cross-country TTOs within various contexts involving even more parties in the technology transfer processes (scientists, industrial stakeholders, business developers, etc.). Furthermore, it would be meaningful to conduct research on trying to find out what organizational structure is the most suitable for TTOs at the universities, what kind of management practices work best, or similar. To add, this study is a pioneer in the context of ECIU, therefore, more aspects related to this topic (such as, for example, innovation ecosystems and TTO performance related to its role in those ecosystems, or a mechanism of sharing best practices among ECIU TTOs to increase their performance, etc.), could be explored, as it's quite complex. Such studies would allow obtaining insights that are more practical as well as gaining additional knowledge regarding the performance of TTOs, which would help to develop their functionality.

\section{Conclusions}

There are many internal and external factors mentioned in scientific literature, which are qualified as important and influencing technology transfer in TTOs. The systematic approach of understanding them is required for managers to manage TTO's activities effectively.

This empirical study allowed to reason the identified factors based on the international (European) context. Comprehensive strategy in regard to the role of the university and the focus of TTO activities was reasoned through reaching a common understanding of the need for the university to establish such entity as TTO. Relationships with investors were specified as essential in creating an infrastructure for innovation, sponsoring R\&D activities, and enabling commercialization of new technologies. Networking was emphasized through the importance of continued collaboration between universities and industries on a personal level. A separate unit for relations with enterprises was highlighted through the possibility to communicate efficiently based on wellarranged structural solutions. To continue, the business experience of the staff of TTO was discussed in relation to professional communication and beneficial value for TTO activities. However, the diversity of backgrounds related to economic, technological, and legal expertise was distinguished as important for the performance of TTOs.

The results of this study contribute to the present body of knowledge in technology transfer literature as well as practice. Among others, the research carried out in this study adds novelty to the existing literature by creating and validating the proposed framework of factors influencing the performance of TTOs classified according to subject similarity into six groups. Practical significance reveals in the uniqueness of this study because of its focus on internal managerial factors instead of external regulation. Focusing 
on the emphasized aspects of this study the leaders of TTOs might improve the internal processes of their TTOs and even start initiating changes on the external forces, which have an impact on the performance of such offices.

To add, this study contributes by analysing the international context of TTOs representing different period of existence (from 5 to 38 years at the time the study was conducted). It confirms the conclusion that longer existing TTOs perform more successfully than the newly established ones, however, it also reveals that they both are challenged by very similar issues. The fundamental difference is that the TTOs with a longer period of existence are more experienced in how to deal with certain challenges in the most efficient way. Meanwhile TTOs existing for a shorter period of time do not have such possibilities merely because of the timeline and, therefore, learning from good practices is essential for them. However, based on the study results, factors influencing the performance of TTOs are indistinguishable according to the age of TTO or their country of operation. The latter insight is of significant importance as cross-country research on this topic has been very limited so far.

To conclude, as the performance of TTOs remains a challenging topic for many universities around the world, this empirical study allows recognizing the differences and similarities of TTOs established at ECIU members. The latter are benefitting from this study by learning from good practices since their objectives are similar and, therefore, the know-how exchange among them is of extreme value.

\section{References}

Algieri, B., Aquino, A., \& Succurro, M. (2013). Technology Transfer Offices and Academic Spin-off Creation: The Case of Italy. Journal of Technology Transfer, 38, 382-400. https://doi.org/10.1007/s10961-011-9241-8

Anderson, T. R., Daim, T. U., \& Lavoie, F. F. (2007). Measuring the efficiency of university technology transfer. Technovation, 27(5), 306-318. https://doi.org/10.1016/j.technovation.2006.10.003

Arque-Castells, P., Rui M. Cartaxo, R. M., Garcia-Quevedo, J., \& Godinho, M. M. (2016). Royalty Sharing, Effort and Invention in Universities: Evidence from Portugal and Spain. Research Policy, 45, 1858-1872. https://doi.org/10.10 16/j.respol.2016.06.006

Balderi, C., Butelli, P., Conti, G., Di Minin, A., \& Andrea Piccaluga, A. (2007). Towards an Italian Way in the Valorisation of Results from Public Research. Impresa Progetto, 1, 1-32. Available at: https://www.impresapro getto.it/sites/ impresaprogetto.it/files/articles/ip_1-07_saggio_piccaluga.pdf

Baldini, N. (2006). University patenting and licensing activity: A review of the literature. Research Evaluation, 15(3), 197-207. https://doi.org/10.3152/147154406781775878

Bathelt, H., Kogler, D., F., \& Munro, K. M. (2010). A Knowledge-based Typology of University Spin-offs in the Context of Regional Economic Development. Technovation, 30, 519-532. https://doi.org/ https://doi.org/10.1016/ j.technovation.2010.04.003

Buenstorf, G., \& Geissler, M. (2012). Not Invented Here: Technology Licensing, Knowledge Transfer and Innovation Based on Public Research. Journal of Evolutionary Economics, 22, 481-511. https://doi.org/10.1007/s00191-0110261-1

Caldera, A., Debande, O. (2010). Performance of Spanish universities in technology transfer: An empirical analysis. Research policy, 39, 1160-1173. https://doi.org/10.1016/j.respol.2010.05.016

Campbell, A. F. (2007). How to set up a technology transfer office: experiences from Europe, in Krattiger, A., Mahoney, R.T. and Nelson, L. (Eds.): Intellectual Property Management in Health and Agricultural Innovation: A Handbook of Best Practices, MIHR: Oxford, UK. University technology transfer office. Available at: http://www.iphandbook.org /handbook/chPDFs/ch06/ipHandbook-Ch\%2006\%2003\%20Campbell\%20Establishing\%20TTOs-Europe.pdf

Carlsson, B., \& Frith, A. (2002). Technology transfer in United States universities: a survey and statistical analysis. Journal of Evolutionary Economics, 12, 199-232. https://doi.org/10.1007/s00191-002-0105-0

Chapple, W., Lockett, A., Siegel, D. S., \& Wright, M. (2005). Assessing the Relative Performance of University Technology Transfer Offices in the UK: Parametric and Non-Parametric Evidence, Research Policy, 34(3), 369-34. https://doi.org/10.1016/j.respol.2005.01.007

Curi, C., Daraio, C., \& Llerena, P. (2012). University Technology Transfer: How (in-) efficient are French Universities? Technical Report. https://doi.org/10.1093/cje/bes020

De Beer, C., Secundo, G., Passiante, G. \& Schutte, C., S., L. (2017) A mechanism for sharing best practices between university technology transfer offices. Knowledge Management Research and Practice, 15(4), 523-532. https://doi.org/10.1057/s41275-017-0077-3

Debackere, K., \& Veugelers, R. (2005). The Role of Academic Technology Transfer Organizations in Improving Industry Science Links. Research Policy, 34, 321-342. https://doi.org/10.1016/j.respol.2004.12.003

del Barrio-Castro, T., \& Garcia-Quevedo, J. (2009). The Determinants of University Patenting: Do Incentives Matter? Working Paper No 13/2009. Barcelona: Institut d'Economia de Barcelona. https://dx.doi.org/10.2139/ssrn.1825014 
Fai, F., M., de Beer, C. \& Schutte, C., S., L. (2018). Towards a novel technology transfer office typology and recommendations for developing countries, Industry and Higher Education 2018, 32(4) 213-225 https://doi.org/10.11 $77 / 0950422218780614$

Fini, R., Fu, K., Mathisen, M. T., Rasmussen, E., Wright, M. (2016). Institutional determinants of university spin-off quantity and quality: a longitudinal, multilevel, cross-country study. Small Bus Econ 48, 361-391. https://doi.org/10.10 07/s11187-016-9779-9

Fini, R., Grimaldi, R., \& Sobrero. M. (2009). Factors Fostering Academics to Startup New Ventures: An Assessment of Italian Founders' Incentives. Journal of Technology Transfer, 34, 380-402. https://doi.org/10.1007/s10961-008-9093-Z

Foltz, J., Barham, B., \& Kim, K. (2000). Universities and Agricultural Biotechnology Patent Production. Agribusiness, 16(1), 82-95. https://doi.org/10.1002/(SICI)1520-6297(200024)16:1<82::AID-AGR7>3.0.CO;2-V

Frederick, P., Granieri, M. (2015). Development of a holistic tool to identify barriers to success for technology transfer offices. Paper was presented at Financing Knowledge Transfer in Europe (FinKT), Rimini, 16-17. http://dx.doi.org/10.2139/ssrn.2596508

Friedman, J., \& Silberman, J. (2003). University Technology Transfer: Do Incentives, Management, and Location Matter? The Journal of Technology Transfer January, 28(1), 17-30. https://doi.org/10.1023/A:1021674618658

Goldfarb, B., \& Henrekson, M. (2003). Bottom-up versus top-down policies towards the commercialization of university intellectual property. Research Policy, 32(4), 639-658. https://doi.org/10.1016/S0048-7333(02)00034-3

Graham, R. (2013). Technology Innovation Ecosystem Benchmarking Study: Key findings from Phase 1, MIT Skoltech Initiative. Available at: https://www.rhgraham.org/RHG/Recent_projects_files/Benchamrking\%20study\%20$\% 20$ Phase $\% 201 \% 20$ summary\%20.pdf

Harman, G. (2010). Australian university research commercialization: perceptions of Technology Transfer specialists and science and technology academics. Journal of Higher Education Policy and Management, 32(1), 69-83. http://doi.org/10.1080/13600800903440568

Heisey, P. W., \& Adelman, S. W. (2011). Research Expenditures, Technology Transfer Activity, and University Licensing Revenue. The Journal of Technology Transfer, 36(1), 38-60. https://doi.org/10.1007/s10961-009-9129-z

Hsu, P. H., Tian, X., \& Xu, Y. (2014). Financial development and innovation: cross-country evidence. Journal of Financial Economics, 112(1), 116-135. https://doi.org/10.1016/j.jfineco.2013.12.002

Hulsbeck, M., Lehmann, E. E., \& Starnecker, A. (2013). Performance of technology transfer offices in Germany. Technol Transf, https://doi.org/10.1007/s10961-011-9243-6

Hunady, J., Orviska, M., \& Pisar, P. (2018). The Effect of Higher Education on Entrepreneurial Activities and Starting Up Successful Businesses, Engineering Economics, 29(2), 226-235. https://doi.org/10.5755/j01.ee.29.2.19069

Jasinski, A. (2009). Barriers for Technology Transfer: the case of a country in transition. Journal of Technology Management in China, 4(2), 119-113. https://doi.org/10.1108/17468770910964984

Kamariah, I., Omar, W., Z., W., \& Majid, I. A. (2011). The Commercialisation Process of Patents by Universities. African Journal of Business Management, 5, 7198-7208. https://doi.org/10.5897/AJBM09.255

Kenney, M., \& Patton, D. (2001). Does Inventor Ownership Encourage University Research derived Entrepreneurship? A Six University Comparison. Research Policy, 40, 1100-1112. https:/doi.org/10.2139/ssrn.1847184

Kim, J., Anderson, T., \& Daim, T. (2008). Assessing university technology transfer: a measure of efficiency patterns. International Journal of Innovation and Technology Management, 5(4), 495-526. https://doi.org/10.11 42/S0219877008001497

Krucken, G., Meier, F., \& Muller, A. (2007). Information, cooperation, and the blurring of boundaries-technology transfer in Germany and American discourses. Higher Education, 53(6), 675-696. https://doi.org/10.1007/s10734-004-7650-4

Kruss, G., \& Visser, M. (2017). Putting university-industry inter- action into perspective: a differentiated view from inside South African universities. Journal of Technology Transfer, 42(4), 884-908. https://doi.org/10.1007/s10961-0169548-6

Lach, S., \& Schankerman, M. (2004). Royalty sharing and technology licensing in universities, Journal of the European Economic Association, 2 (2/3), 252-264. https://doi.org/10.1162/154247604323067961

Lafuente, E., \& Berbegal-Mirabent, J. (2017). Assessing the productivity of technology transfer offices: an analysis of the relevance of aspiration performance and portfolio complexity, Springer Science+Business Media, LLC 2017. https://doi.org/10.1007/s10961-017-9604-x

Lambert, R. (2003). Lambert Review of Business-University Collaboration. Her Majesty’s Stationery Office.

Lee, J. N., \& Bray, M. J. (2000). University revenues from technology transfer licensing fees vs. equity positions. Journal of Business Venturing, 15, 385-392. https:/doi.org/10.1016/S0883-9026(98)00034-2 
Ruta Zmuidzinaite, Sandra Zalgeviciene, Lina Uziene. Factors Influencing the Performance of Technology Transfer ...

Libecap, G. (2005). University Entrepreneurship and Technology Transfer: Process, Design, and Intellectual Property, Elsevier, AZ. Available at: https://pages.uoregon.edu/ajnelson/NelsonByers-2005.pdf; https://doi.org/10.1016/S10484736(2005)16

Lockett, A., Wright, M., \& Franklin, S. (2003). Technology Transfer and Universities' Spin-Out Strategies. Small Business Economics, 20(2), 185-200. https://doi.org/10.1023/A:1022220216972

Markman, G. D., Phan, P. H., Balkin, D. B., \& Gianodis, P. T. (2005). Entrepreneurship and university-based technology transfer. Journal of Business Venturing, 20(2), 241-263. https:/doin.org/10.1016/j.jbusvent.2003.12.003

Meyer, Martin S., \& Puay Tang. (2007). Exploring the "Value" of Academic Patents: IP Management Practices in UK Universities and Their Implications for Third-stream Indicators. Scientometrics 70, 415-440. https://doi.org/10.10 07/s11192-007-0210-9

Muscio, A. (2010). What drives the university use of technology transfer offices? Evidence from Italy. Journal of Technology Transfer, 35(2), 181-202. https://doi.org/10.1007/s10961-009-9121-7

Nilsson, A. S., Rickne, A., \& Bengtsson, L. (2010). Transfer of Academic Research: Uncovering the Grey Zone, Journal of Technology Transfer, 35, 617-636. https://doi.org/10.1007/s10961-009-9124-4

Perez, M., \& Sanchez, A. M. (2003). The development of university spin-offs: early dynamics of technology transfer and networking, Technovation, 23, 823-31. https://doi.org/10.1016/S0166-4972(02)00034-2

Plewa, D., Quester, P., \& Baaken, T. (2006). Organizational culture differences and market orientation: an exploratory study of barriers to university-industry relationships. International Journal of Technology Transfer and Commercialization, 5(4), 373-389. https://doi.org/10.1504/IJTTC.2006.013344

Salter, A., Bruneel, J., \& D'Este, P. (2009). Investigating the factors that diminish the barriers to university-industry collaboration. Paper to be presented at the Copenhagen Business School Summer Conference 2009. https://doi.org/10.1016/j.respol.2010.03.006

Santoro, M. D., \& Gopalakrishnan, S. (2000). The institutionalization of knowledge transfer activities within industryuniversity collaborative ventures. J. Eng. Technol. Manage. 17, 299-319. https://doi.org/10.1016/S0923-4748 (00)00027-8

Secundo, G., De Beer, C., \& Passiante G. (2016). Measuring university technology transfer efficiency: a maturity level approach. Measuring Business Excellence, 20(3), 42-54. https://doi.org/10.1108/MBE-03-2016-0018

Secundo, G., \& Elia, G. (2014). A performance measurement system for academic entrepreneurship: a case study. Measuring Business Excellence, 18(3), 23-37. https://doi.org/10.1108/MBE-11-2013-0061

Sellenthin, M. (2009). Technology transfer offices and university patenting in Sweden and Germany. Journal of Technology Transfer, 34(6), 603-620. https://doi.org/10.1007/s10961-009-9108-4

Shane, S. (2004). Encouraging University Entrepreneurship? The Effect of the Bayh-Dole Act on University Patenting in the United States. Journal of Business Venturing, 19, 127-51. Available at: https://ideas.repec.org/a/eee/jbvent/ v19y2004i1p127-151.html; https://doi.org/10.1016/S0883-9026(02)00114-3

Siegel, D. S., Waldman, D. A., \& Link, A. (2003a). Assessing the impact of organizational practices on the relative productivity of university Technology Transfer offices: an exploratory study. Research Policy, 32(1), 27-48. https://doi.org/10.1016/S0048-7333(01)00196-2

Siegel, D. S., Waldman, D. A., Atwaterb, L. E., \& Link, A. N. (2003b). Commercial knowledge transfers from universities to firms: improving the effectiveness of university-industry collaboration. Journal of High Technology Management Research, 4(1), 111-133. https://doi.org/10.1016/S1047-8310(03)00007-5

Siegel, D. S., Veugeler, R., \& Wright, M. (2007). Technology Transfer offices and commercialization of university intellectual property: performance and policy implications. Oxford review of Economic Policy, 24(4), 640-660. https://doi.org/10.1093/oxrep/grm036

Siegel, D. S., Wright, M., Chapple, W., \& Lockett, A. (2008). Assessing the Relative Performance of University Technology Transfer in the US and UK: a Stochastic Distance. https://doi.org/10.1080/10438590701785769

Tahvanainen, A. J., \& Hermans, R. (2011). Making sense of TTO production function: university technology transfer offices as process catalysts, knowledge converters and impact amplifiers. Working paper 1236, Research Institute of the Finnish Economy (ETLA), Helsinki, January. Available at: https://www.econstor.eu/handle/10419/44558

Thursby, J. G., \& Kemp, S. (2002). Growth and Productive Efficiency of University Intellectual Property Licensing. Research Policy, 31, 109-24. https://ideas.repec.org/a/eee/respol/v31y2002i1p109-124.html; https://doi.org/10.10 16/S0048-7333(00)00160-8

Thursby, J. G., \& Thursby, M. C. (2002). Who is Selling the Ivory Tower? Sources of Growth in University Licensing. Management Science, 48, 90-104. Available at: https://ideas.repec.org/a/inm/ormnsc/v48y2002i1p90-104.html; https://doi.org/10.1287/mnsc.48.1.90.14271 
Thursby, J. G., Jensen, R., \& Thursby, M. C. (2001). Objectives, characteristics and outcomes of university licensing, a survey of major US universities. Journal of Technology Transfer, 26(1/2), 59-72. https://doi.org/10.10 23/A:1007884111883

Tseng, A. A., \& Raudensky, M. (2014). Performance Evaluations of Technology Transfer Offices of Major US Research Universities. Journal of Technology Management \& Innovation, 9(1), 0718-2724. https://doi.org/10.4067/S071827242014000100008

Ustundag, A., Ugurlu, S., \& Kilinc, M. S. (2011). Evaluating the performance of technology transfer offices. Journal of Enterprise Information Management, 24(4), 322-337.https://doi.org/10.1108/17410391111148576

Villani, E., Rasmussen, E., \& Grimaldi, R. (2017). How intermediary organizations facilitate university- industry technology transfer: a proximity approach, Technological Forecasting and Social Change, 114, 86-102. https://doi.org/10.1016/j.techfore.2016.06.004

Vinig, T., \& Lips, D. (2015). Measuring the performance of university technology transfer using meta data approach: the case of the Dutch universities. Journal of Technology Transfer, 40(6), 1034-1049. https://doi.org/10.1007/s10961014-9389-0

Weckowska, D. M. (2014). Learning in university technology transfer offices: transactions-focused and relations-focused approaches to commercialization of academic research. Technovation, 41(42), 62-74. https://doi.org/10.101 6/j.technovation.2014.11.003

York, A. S., \& Ahn, M. J. (2012). University technology transfer office success factors: a comparative case study. International Journal of Technology Transfer and Commercialization (IJTTC), 11(1/2). https://doi.org/10.1504/IJT TC.2012.043910

\section{Authors' biographies}

Rūta Žmuidzinaitė is an advisor at the Research and Innovation Unit, Department of Research and Internationalization, University of South-Eastern Norway. She holds 2 Master's degrees in Social Sciences: Innovation Management and Entrepreneurship, obtained in 2018 from Kaunas University of Technology (Lithuania), and Culture, Organization, and Management, obtained in 2014 from Vrije University Amsterdam (the Netherlands). Ruta's interest areas are knowledge/technology transfer, innovative and engaged universities, academic entrepreneurial ecosystems, value creation in externally funded research projects, strategic partnerships, responsible research and innovation (RRI), research integrity, sustainability.

Žalgevičienė Sandra is a Community and Sales coordinator at Startup Norway (Chr. Krohgs gate 1, NO-0186, Oslo, Norway). She holds a Master's degree in Social Sciences: Innovation Management and Entrepreneurship, obtained in 2018 from Kaunas University of Technology. She has also been an intern at the Katapult Accelerator, National Innovation and Entrepreneurship Centre in Lithuania, and the Embassy of the Republic of Lithuania in Norway. In addition to all of this, Sandra was a Technology Transfer Specialist at National Innovation and Entrepreneurship Centre in Lithuania.

Dr Užiene Lina is an associate professor at the School of Economics and Business, Kaunas University of Technology. She received a Ph.D. in Management and Business Administration in 2005. Her current research focuses on national policy-making based on effective management of intellectual resources, digital transformation, and the development of innovation-oriented infrastructures. She is a member of different scientific committees and bodies responsible for the development of methodologies and the transfer of knowledge from educational systems to business practice. She is an author of more than 30 academic publications, books, and chapters. She acts as a national and international expert, a research project manager, and an inspirational speaker to promote innovation leadership and intellectual capital development via educational forums and platforms.

The article has been reviewed. Received in April 2020; accepted in June 2021.

This article is an Open Access article distributed under the terms and conditions of the Creative Commons Attribution 4.0 (CC BY 4.0) License (http://creativecommons.org/licenses/by/4.0/). 